\title{
ROMANIA: STILL IN CRISIS (?)
}

\author{
Jánossy Zsuzsanna \\ PhD student \\ Enyedi György Regionális Tudományok Doktori Iskola, Szent István Egyetem \\ E-mail: zs1janossy@yahoo.com
}

\begin{abstract}
The starting point of the study lies in the fact that it analyzes the crisis not only as the cause of economic recession, but it also presents its effects upon society.

As human development index cannot be calculated based only on economic well-being, neither is the economic development of a country sufficient to establish its place in global development ranking. The society for which a country's economy must function and develop is the other most decisive factor of development level. Society is the one to dispose of human resources, which represent the basis of national economy.

The data and results used in this study reflect that the global crisis represents the cause of recession in Romania's economy and that due to its internal economic imbalances, the country is still trapped in the rift. At the end of the study, the reader is free to decide whether the "status report" on Romania's situation is a statement or a question.
\end{abstract}

Keywords: crisis, budget, European integration, convergence

JEL classification: $\mathrm{H} 12, \mathrm{H} 6, \mathrm{O} 43, \mathrm{P} 52$

\section{Materials and methods}

While processing this topic, I mainly rely upon national specialized literature (books, magazines, articles) and analyze Romania's socio-economic situation based on statistical data.

The applied indicators and methodology require the collection and management of the appropriate quantity and quality of data. I use national databases (National Institute of Statistics, Central Regional Development Agency) and illustrate them with graphics prepared in Excel program. As primary sources, I rely on the data of the Statistical Yearbook of the year 2012, the online statistical database TEMPO and the results published by the economics website called "Logica Economica".

\section{Introduction}

At the moment of joining the European Union in 2007, Romania occupied the $11^{\text {th }}$ place in the ranking of the largest economies, while in the years prior to that, its economy was remarkably powerful and developing (Coteiu-Nasui 2010). Before achieving this, it fulfilled the Copenhagen criteria, which require the existence of institutional systems of a democratic state, a functioning market economy, the adoption of economic and monetary union, as well as the harmonization of law. 
In order to meet these requirements, major reorganizations were needed (Simon 2003). In the years prior to the accession, the development processes made Romania catch up with the economy of the EU, which entailed the growth of investors' confidence and of the ability to attract capital, thus, resulting in impressive economic growth (Coteiu-Nasui 2010). This process was inversed by the crisis, which deepened in 2008-2009. In the year 2008, specialists considered that the Romanian economy resisted the crisis (Ciulu 2009), however, in 2009, the spectacular growth of the previous year turned. The year 2009 proved the exposure to the crisis, which represented the price of the impressive growth of previous years - insolvency could be avoided only with the help of the IMF.

After the change of regime, Romania was transformed from a state-regulated and socialist type of economy to a developing market economy, though it partly preserved its traditional industrial arrangements. The 1990s were still characterized by the delay of the shock of transition and slow economic growth. Nevertheless, in ten years, Romania, which offered more and more favorible opportunities to foreign investors, became one of the most dinamically developing states of the East-Central European region, gradually introducing economic reforms, and thus, involving large amounts of foreign capital.

It was typical to the businesses that revived the Romanian economy that they were foreign direct investments or of foreign majority ownership. This great interest is shown by the fact that, after Turkey, Romania was the second most wanted country for placing investments from among the states waiting to join the EU or those that joined in 2007 (Pauwels-Ionita 2008).

However, the dynamic economic growth had its price - the industrial and export-oriented growth made the country's economy vulnerable given the fact that numerous structural and institutional weaknesses emerged (Ciulu 2009).

Economic processes should have been carefully examined within integration, especially given the fact that, due to the scarce supply of capital expected in world economy, it became necessary to modify this modernization model, as well as it would have been adequate to elaborate a model that focused more on internal savings.

The economy was functioning according to the motto "We work, not think" considering the fact that not only the quantity of the capital, but also its way of investment would have been important.

The bright side of the issue is that, due to the success of economic restructuring, unemployment was reduced and export increased in sectors that survived the economic transformation of the 1990s. Financial markets also developed, and as a result of the facilitation of accessing credits, consumption, the average level of salaries, as well as the standard of living increased. By the year 2005, inflation was also reduced to a value under $10 \%$, which meant the result of a long struggle of the economy (Ciulu 2009, Eurostat 2011).

\section{Analyses and results}

As it can be seen in diagram no. 1, Romania, as a country wishing to join the EU, enjoyed the subsidies resulting from the pre-accession funds of the EU for a long time, subsidies that were used mainly to improve services: to strengthen administrative and judicial capacity, to implement constructions, to improve infrastructure, education and health care (Balázs 2006). 


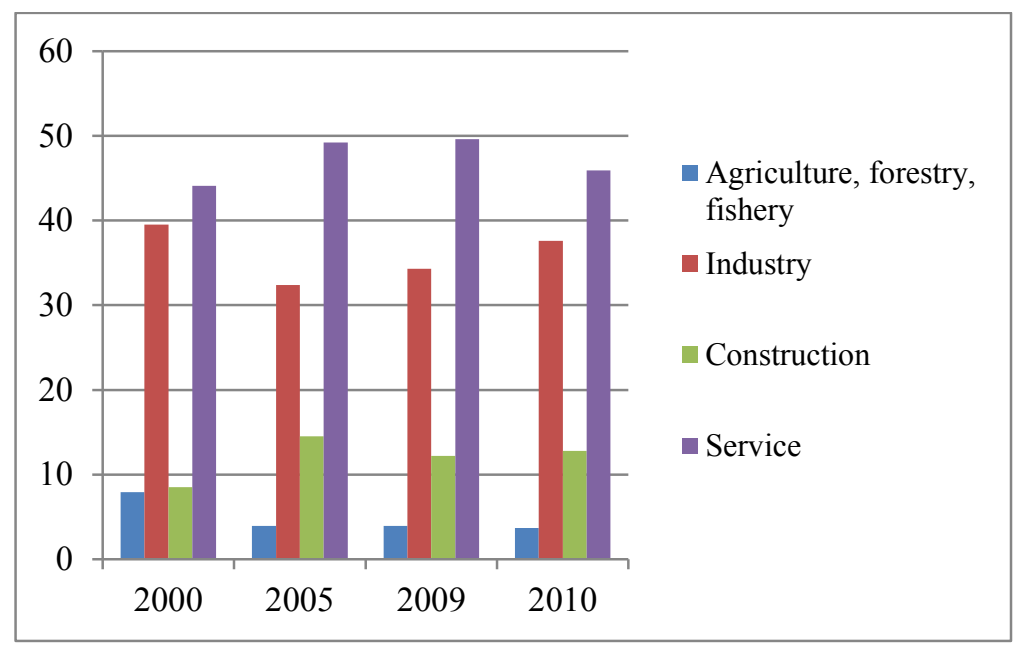

Diagram 1.: Investments in Romania according to economic sectors (\%) Edited by the author. Source: National Institute of Statistics, Romania

Besides this, many production and processing industries still operate with outdated technology and high costs, mining and extractive industries receive minor investments, which shows that no new borings are carried out, no new mineral deposits are searched, the existing ones are not being modernized and no new investors appear.

As main sectors of the national economy contribute to the production of GDP, the same way do investments occur into these sectors, as shown in diagram no. 2.

As a result of the tightening of crediting activities, the SME sector that was gaining ground in the last decade and was considered one of the main pillars of Romanian economy found itself in a very difficult situation (Vorniceanu et al. 2009). As a consequence of the stock market crash, the private sector was affected by property loss. All these impacts resulted in the reduction of consumption and investments, the fall of GDP, as well as in the growth of unemployment (Marer 2010). The growth rate of GDP fell from 7.3\% plus in 2008 to $7.1 \%$ minus in 2009, which is a result much worse than the average decline of $4.2 \%$ of EU member states, while, in these years, unemployment rate increased from 4\% to 6,3\% (Eurostat 2011, IMF 2010).

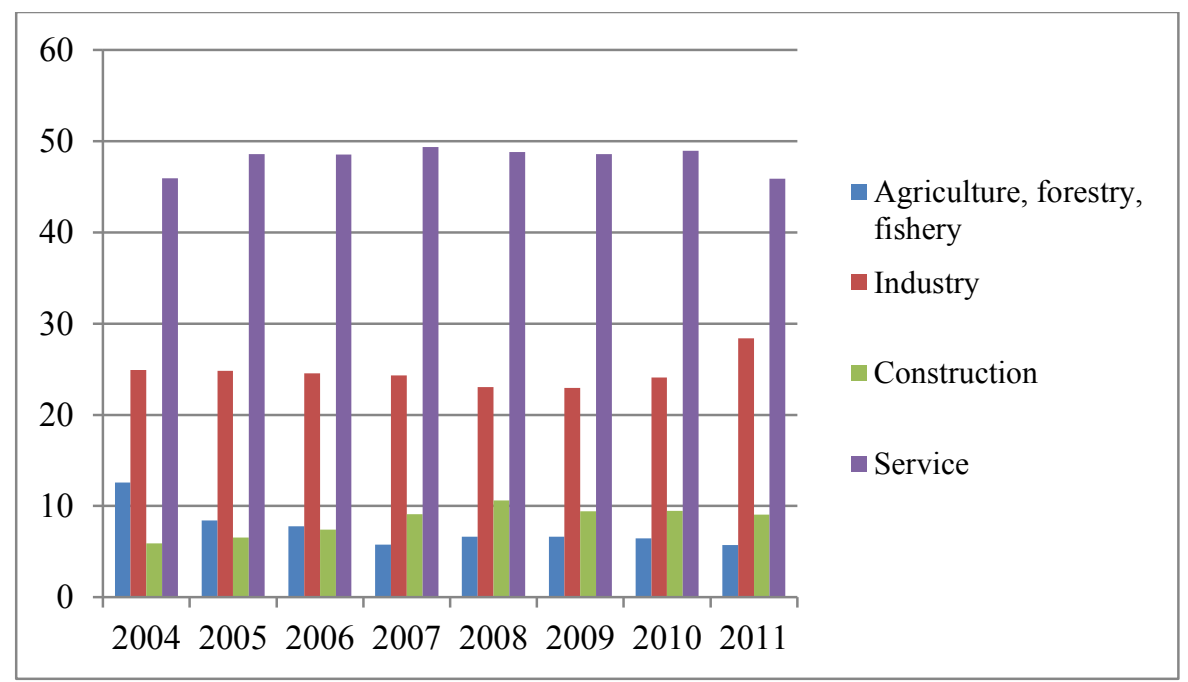

Diagram 2.: Contribution of economic sectors to the production of GDP (\%)

Edited by the author. Source: National Institute of Statistics, Romania 
Prior to the crisis, the economic growth in Bulgaria and Romania was controled mainly by domestic demand, especially the contribution of net exports to growth fell into negative territory, while in Central-European countries, the composition of growth was more balanced (European Commission, 2009a). In Baltic countries, an important area of imbalances was the active real estate market, which collapsed during the crisis.

The different composition of foreign capital can be also observed in the banking sector. In new member states, aproximately $60-90 \%$ of bank assets are in foreign hands, while in old member states, this ratio is between 10-50\% (European Central Bank, 2010, p. 20).

Like in other countries of the region, first appearing as a financial and liquidity crisis, the depression caused real economic consequences due to the reduction in crediting, in the way that the foreign parent banks withdrew their allocated liquid assets, thus meeting their own capital adequacy requirements.

In the year 2009, the interest rates also increased because the bond market priced the financing difficulties of the jeopardized Romanian economy into its return requirements. Regarding the changes in budget, it can already be seen in diagram no. 3 that the country ended the year 2008 in alarming deficit, while in 2009 it became clear that this budget could not stand on its feet. The increase in public debt can be explained by the fact that the state "bought" the crisis through economic recovery, like the other Eastern-European states, but this budget could not stand without further loans.

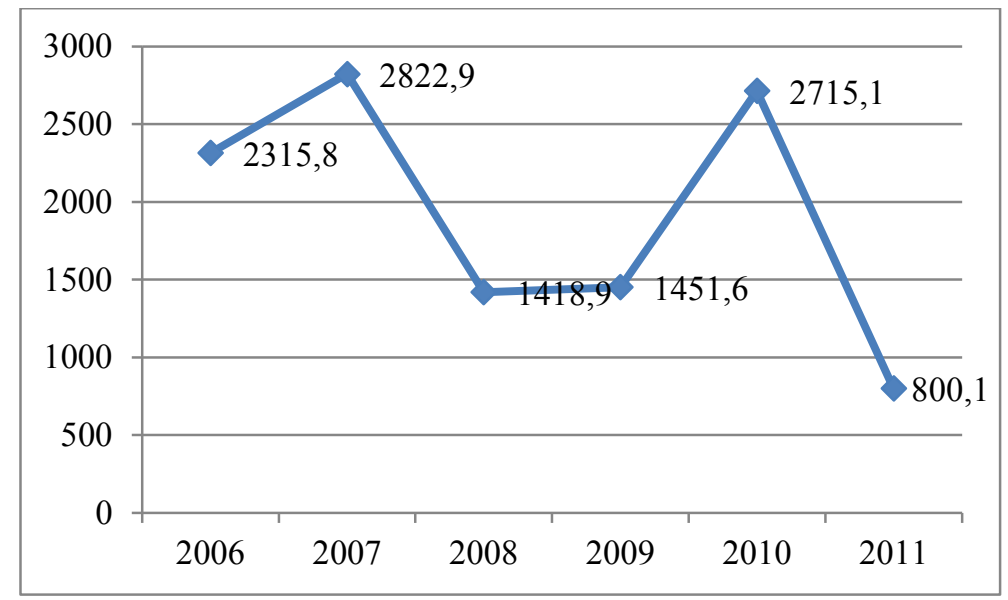

Diagram 3.: Budget in Romania (million Lei)

Source: The 2012 Statistical Yearbook of the National Institute of Statistics, Romania, Regional Office of Statistics, Alba

The effect of the adjustment implemented in the wages of the countries most affected by the crisis is already reflected in the changes of relative consumption situation. If we are to compare either real wages, or real unit labor costs, the most significant reductions were implemented in Latvia, Lithuania, Hungary and Romania.

The largescale balance of payments deficit and the consumer indebtedness in foreign currencies of Romania, as well as the freezing of foreign credit in the second half of 2008 inclined the government to resort to the IMF and the EU in March 2009, and to the World Bank in July 2009 for credit. 
The creditors required the reduction of budget expenditures. Accordingly, the government reduced the salaries of civil servants and public employees, as well as the government contribution to health care significantly, increased the value-added tax from $19 \%$ to $24 \%$ and abolished government contribution to heating. After the Constitutional Court of Romania declared the 15-percent reduction in pensions unconstitutional, the government imposed a 16percent tax on them as well. By the year 2011, the government wished to reduce the number of public sector employees by 100000 (Toma 2010). The export subsidies aimed at the retention of heavy industry, which represents one of the pulling forces of the economy, while automobile industry was supported within the framework of the "Rabla Program" (car-wreck).

In order to support small and medium-sized enterprises, the recapitalisation of the Romanian Savings Bank (CEC) and Exim Bank was envisaged, which was accompanied by the establishment of a credit fund for the development of the SME sector.

Another important objective was to control the growth of government deficit, respectively to use the subsidies drawn from EU funds - under strict control - in order to revive the economy. Tax relief was prospected for those who invested and undertook the implementation of the investment in 2010 (Talpos-Avram 2011).

The above-mentioned objectives and measures could not be implemented, so the budget collapsed within a few months. The agreement with the International Monetary Fund was already on the agenda in March 2009, and the country obtained a credit of 20 billion euro, whereof 17.1 billion could already be drawn in 2009. In return, the Monetary Fund stipulated the adoption of new economic key figures (IMF, EU, EBRD 2009). The IMF and the European Committee imposed four basic conditions to Romania: the adjustment of the budget, the constitution of a draft with regard to uniform structure of wages, the reform of tax liability and pension system. According to the opinion of that time of the IMF, despite this help, the years 2009 and 2010 would still represent a very difficult period for the Romanian economy, a fact that eventually was confirmed (Talpos-Avram 2011).

With the help of international guidelines, reforms can be implemented and adopted successfully, though their social reception is doubtful. Initially, the objective of the measures was the inversing of the crisis, which, besides the maintaining of political promises, could not be afforded by the budget. Therefore, great tranformations and structural reforms can represent the chances of recovery only if they are implemented with monetary and fiscal austerity.

As the last step of consolidation of the 2010 budget, two options were available: public sector wage cuts of $25 \%$ or the increase of the general VAT rate from $19 \%$ to $24 \%$ (Talpos-Avram 2011), however, the combined effect of these measures still proved to be insufficient. Therefore, further restrictions were necessary in 2011, for instance, the number of public employees were reduced in the year 2013 as well. 


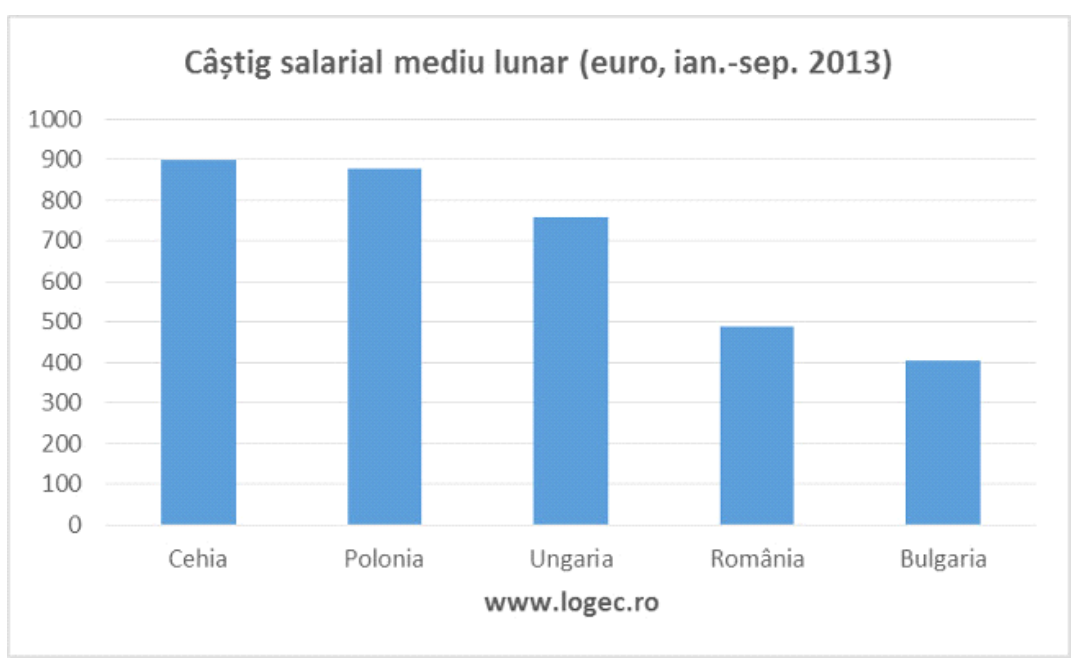

Source: $\underline{w w w \cdot \operatorname{logec} . r o}$

\section{Diagram 4.: Average monthly salary ${ }^{35}$ (Euro)}

The data presented in diagram no. 4 refer to the first three trimesters of the year 2013 and are calculated in Euro, where the Czech Republic is leading with the average monthly salary of 899 Euro, followed by Poland with the average monthly salary of 878 Euro; Hungary has the third place with 759 Euro, Romania is the last but one with 487 Euro (2,216 Lei), and Bulgaria closes the line with 404 Euro.

As it can be seen in diagram no. 5, bank loan repayment rates also increase among individuals because, as a result of the more and more expensive public expenditures, most families fall below the poverty line and they cannot cover their loan coasts from their monthly income.

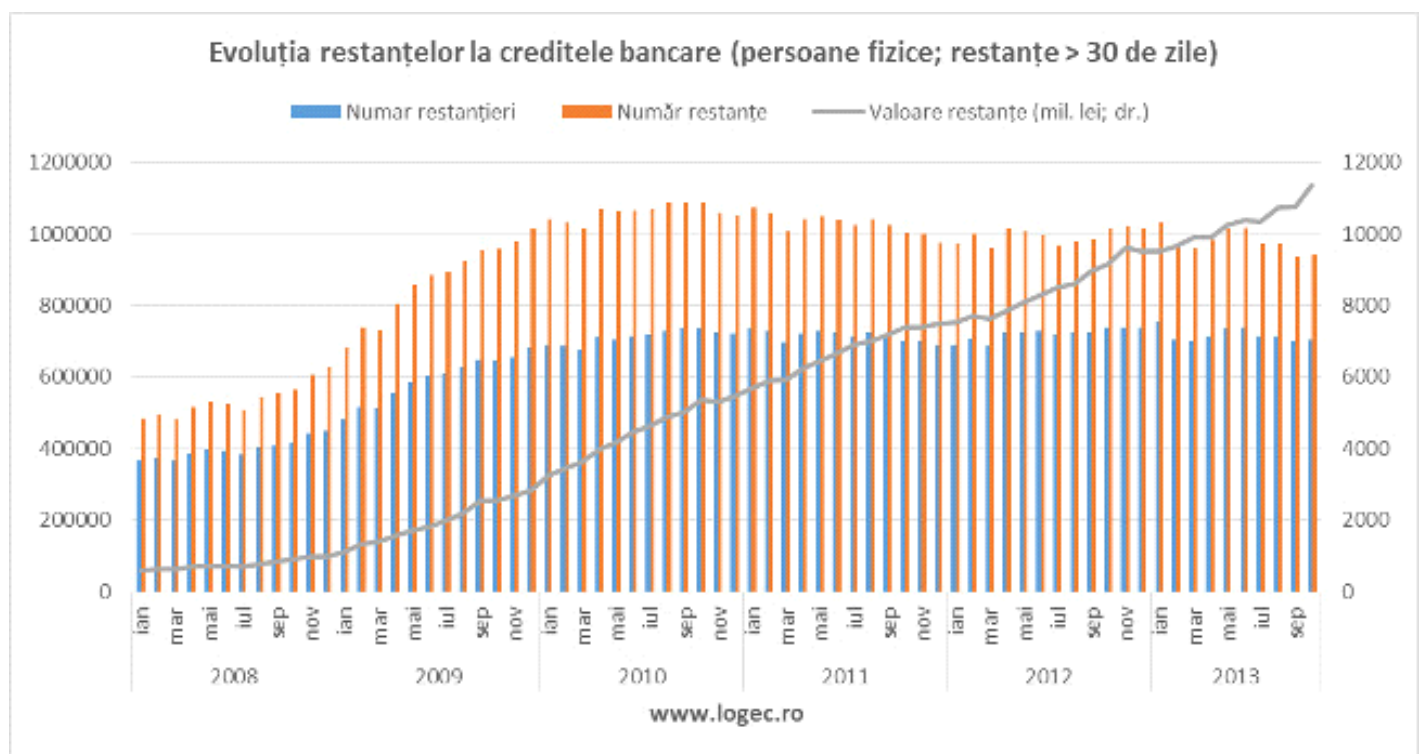

Diagram 5.: The evolution of bank loan repayment rates of individuals (over 30 days) (blue: number of persons in arrears, brown: instalments in arrears, line: value of instalments in arrears, 1000 Lei)

Source: $\underline{w w w . l o g e c . r o}$

\footnotetext{
${ }^{35}$ According to the data obtained from the Institute of Statistics of Hargita County, the average monthly net salary continues to be the lowest in Hargita County, namely 1,091 Lei, preceded by Vaslui County with the average salary of 1,098 Lei. These are the two counties where average monthly net salaries are lower than 1,100 Lei. The huge discrepancy between counties is thought-provoking...
} 
Bank loans are taken out for house building and car purchasing.

After the change of regime, the number of house constructions increased, whereof the majority were implemented from private funds. The positive trend was worsened by the economic crisis, and after 2010 , by the decrease of real estate prices.

Diagram no. 6 illustrates appropriately that the majority of construction works in the analyzed period consists of house building and the establishment of residential parks. This favourable ratio was generated by credit facilities offered by banks, which still could not reach a rising trend again since the economic crisis or, at least, keep the level of the previous year. The decline of real estate prices and of the value of Lei is not favourable for the construction industry.

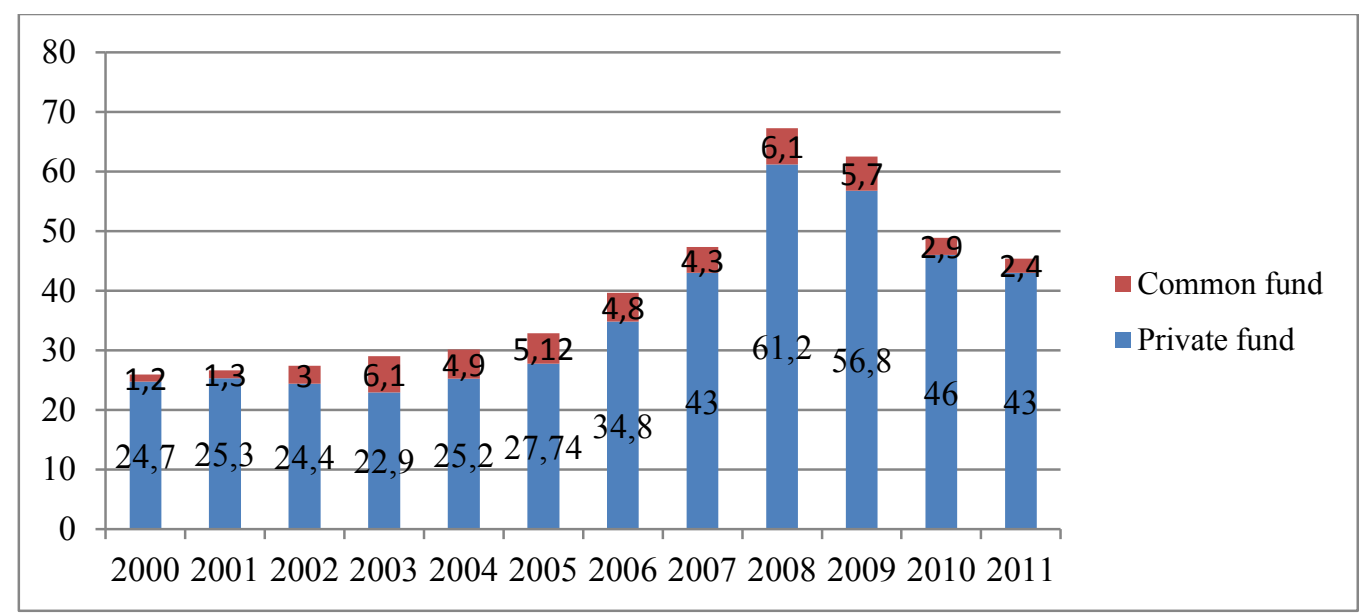

\section{Diagram 6.: Distribution of house construction based on funds in Romania (1000 houses)}

Edited by the author. Source: National Institute of Statistics, Romania

Romania is not recovering yet, it is still struggling with the crisis, cannot adapt to the situation because the national currency is being devaluated, which is difficult to manage by the economy. As it can be seen in diagram no. 7, the Euro-Leu exchange rate cannot approximate the one in 2008 since 2009.

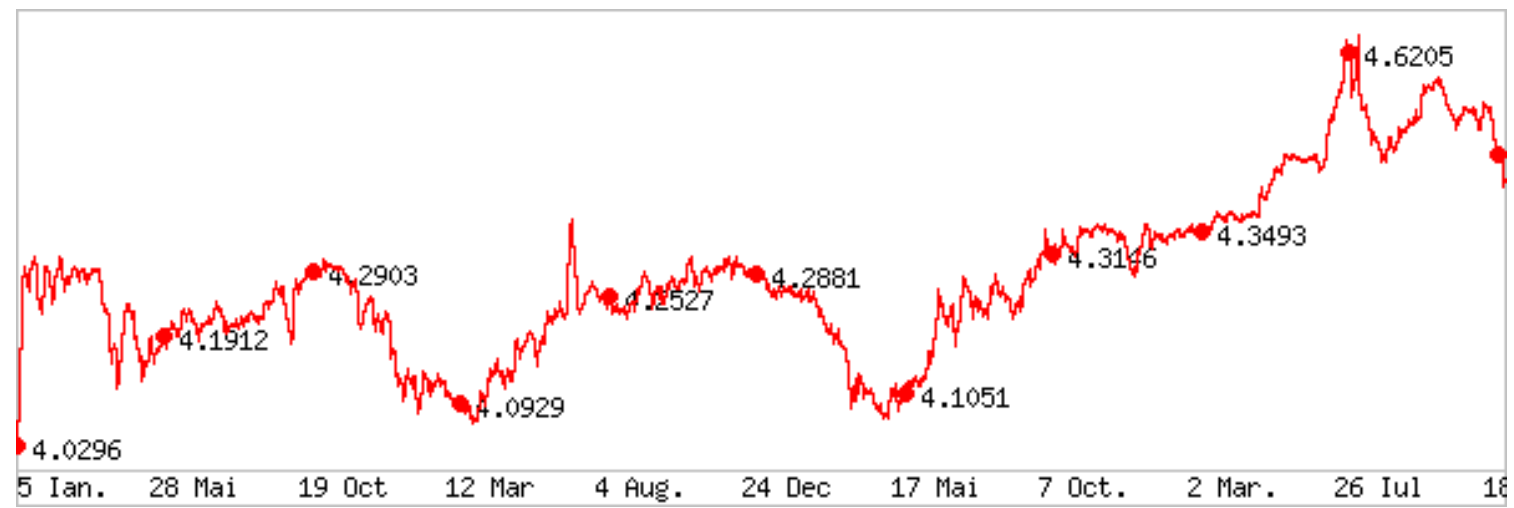

Diagram 7.: Evolution of the euro exchange rate (between January 2009 and December 2012)

Source: $\underline{\text { http://www.cursbnr.ro/grafic-valute }}$ 
Diagram no. 8 illustrates the revival of the vehicle market. This "booming" is the result of the import of used cars and trucks from abroad. The pollution "penalties" imposed in 2011 favoured the sale of new cars, but the reduction of car registration fees introduced in 2012 increased the demand for used ones.

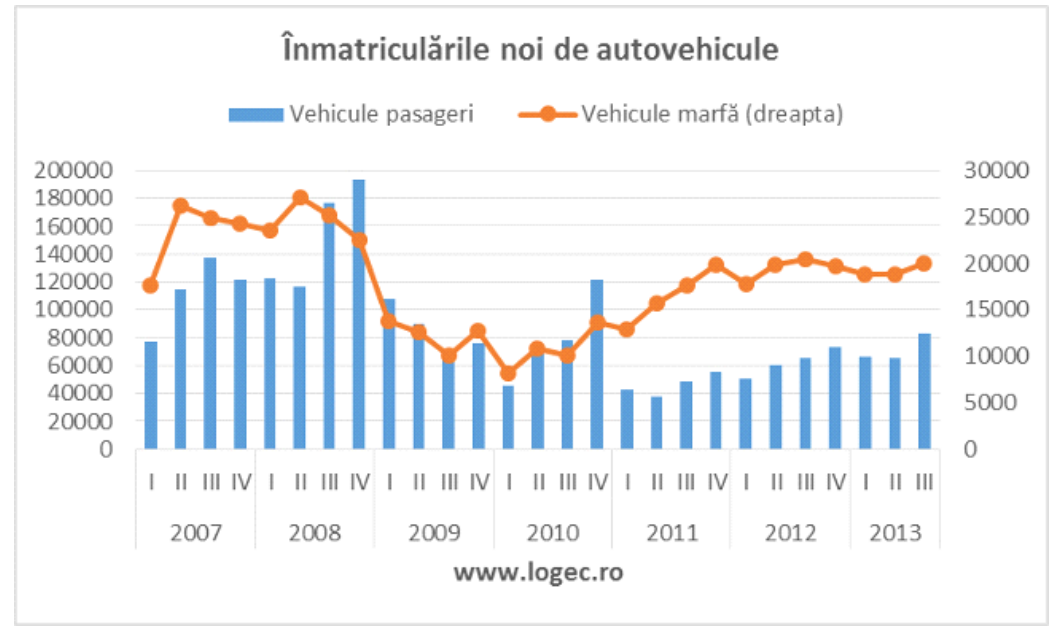

\section{Source: $\underline{w w w \cdot \operatorname{logec} . r o}$}

\section{Diagram 8.: Number of car registrations (blue: cars, brown: trucks)}

According to the $2009 \mathrm{HDR}^{36}$, Romania is ranked $63^{\text {rd }}$ with a $\mathrm{HDI}^{37}$ of 0.837 in 2007 . This ranking reflects a very "modest" situation, which explains the unexploitedness of development potential, and besides, our neighbors - their place in the ranking - also illustrates the poor performance of our country. Trinidad and Tobago also has similar results, while Saint Kitts and Nevis precedes our country with 0.838 and Montenegro follows it with 0.834 .

According to the 2011 ranking, Romania ranked $50^{\text {th }}$ with a HDI of $0.781(84 \%$ of the maximum, Norway's HDI of 0.943 ), with a difference of 0.162 as compared with the first. With this value, Romania is very close to the lower value of the very high human development interval (places 1.-48. reflect very high HDI).

In the period of 2000-2011, Romania made significant progress considering that its HDI growth rate is ranked $2^{\text {nd }}(0.95)$ even among countries with very high HDI, preceded only by the Arab Emirates (1.06).

It must be also noted that the analysis was performed with a specific calculation, which highlights the effect of income upon the value of human development index. More precisely, a non-economic HDI was also calculated for the year 2011. In Romania's case, this value is $7.7 \%$ higher than the general HDI (0.841 as opposed to 0.781$)$. With the non-economic HDI value, Romania ranks $33^{\text {rd }}$ among the 187 countries also analyzed with the same calculation. The phenomenon that the non-economic HDI value is higher than the general HDI is characteristic to those developed countries where all the indices of HDI are of high value.

\footnotetext{
${ }^{36}$ The Human Development Reports of the UNDP (United Nations Development Programm) are a series of reports that have calculated human development indices since 1990, first in 130, then in 182 countries.

${ }^{37}$ The HDI (Human Development Index) consists of the following sub-indices: the starting point in the calculation of gross domestic product (GDP) index was the GDP per capita based on purchasing power parity (in US dollars), life expectancy at birth (state of health), literacy (among population aged above 15 years) and school enrollment rate (level of education: elementary, secondary, higher education).
} 
The three countries that achieved the three highest non-economic HDI value are Australia (0.979), New Zealand (0.978) and Norway (0.975).

As it can be seen in diagram no. 9, after the change of regime, the HDI was decreasing, then it was increasing until 2007, after that, as a result of the economic crisis, the value of the indices begin to fall again.

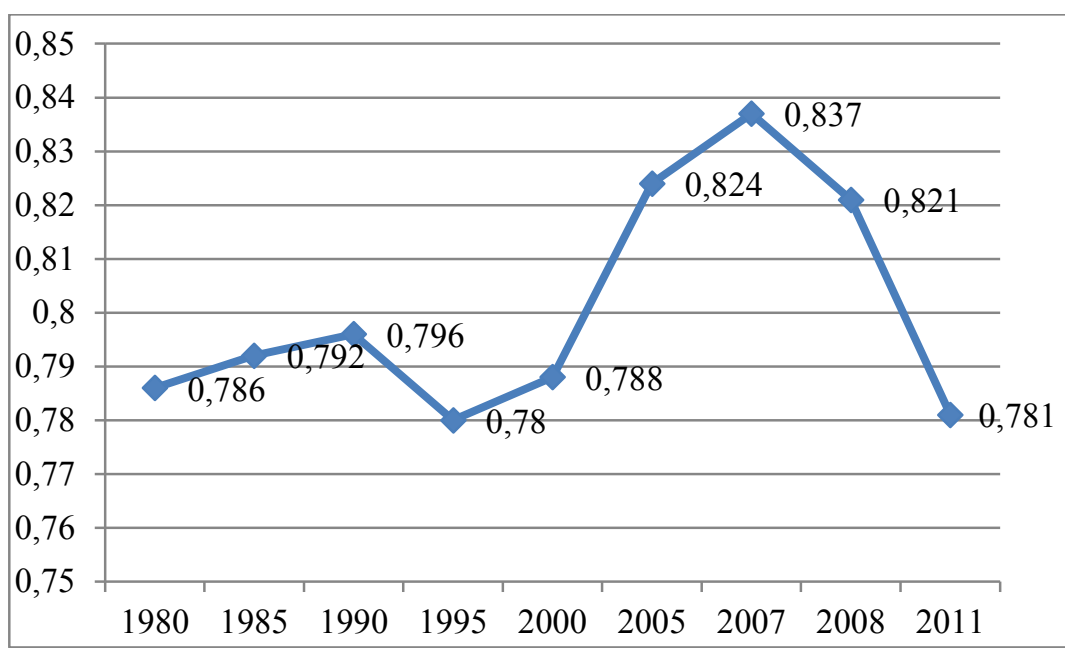

Diagram 9.: HDI value in Romania between 1980 and 2011.

Edited by the author. Source: Human Development Reports UNDP, 2011

In terms of GDP growth, the current situation is not optimistic. After the economic crisis, the value of GDP decreased; a slightly rising trend was to be expected after the year 2010 but this will depend on intensive economic development policies, which presuppose the development of innovation and knowledge base.

Nowadays, the regional inequality of socio-economic systems is essential regarding health status, and as such, it might be influenced by regional policies given the fact that, in case of inequalities in health status, "we always talk about socio-spatial differences, not only about spatial or social ones.” (Jones-Moon, 1987).

The aging population struggles with several diseases, which are difficult to attend by state or private health care facilities or cannot be attended at all. Hospitals struggle with the lack of professionals because low wages alienate young professionals from this sector; most of them going abroad to work.

After rearranging the health care system, many health care facilities were privatized, their services requiring high prices; the part of the population with average income or those in retirement cannot even afford to require such health care services.

Health is a multidimensional concept, it is unequal in space, it can be interpreted in socioeconomic environment (i.e. it is related to development), thus, it is related to regional policies as well. Therefore, it is a proper index of spatial development because low-skilled individuals or those who come from poor families or leave school at an early age spend less time in health and do not even reach average age. 
The decrease of the number of young people participating in education in Romania is also the result of the decreasing number of births; for instance, in 1990, there were 5.6 million pupils, while, by 2007, their number decreased to 4.4 million. However, the number of those participating in higher education increased significantly by now: in the 1990/1991 academic year, 186 thousand, while in the 2007/2008 academic year, 907 thousand students were registered. (National Institute of Statistics, Romania)

The Romanian system of education can become more efficient only with the help of higher government benefits, which aim at quality education from kindergarten to higher education, high level qualification of teachers, as well as at the development of a positive school image.

The quality and distribution of human resources do not always depend on the level of qualification considering that many people do not work in their professions or in appropriate positions. Another negative phenomenon is the growth of unemployment rate, especially among young people given the fact they cannot find a job after graduating from school or university, or they are rejected because of their lack of professional experience.

Another phenomenon is that the profession is not "well paid". Therefore, qualified young professionals work abroad, and most of them settle down as well. The education system of the country should be rearranged as well, for it is not right that, after being trained, young people cannot make a living with the knowledge achieved in this country but they have to offer their abilities to other countries (brain drain).

In the first third of the year 2013, at least one parent of 82,000 children was working abroad; this figure is higher than that of the end of the previous year (based on the data of the National Child Protection Authority and the Ministry of Labour). According to the data, in 58,902 families, one parent, while in 16,305 families, both parents are working abroad. The number of such families increased as compared with the year 2012, when in 57,304 families, one parent, and in 15,889 families, both parents were away from the family.

The number of children who are home and growing without their parents also continues to increase; while in 2012, their number was 79,901, by 2013, this number increased to 82,073. From these children, 23,312 are left without both of their parents, whereof 22,101 are taken care by relatives and 1,058 children are placed in child protection systems. The number of children left with one parent increased from 34,665 to 48,386 .

Seeing these alarming data, a number of questions arise: What kind of disciplinary education do these children receive? Is there anybody who assumes responsibility for them? What kind of elements of society will these children form after they become adults? What will the new generation be like? Why is it necessary to sell the knowledge gained at home in other countries? Why cannot Romania use this potential?

The disintegration of families is the greatest problem of society because the children of such families usually neglect or leave school, mix with bad company, become criminals; this factor might be one generator of the growth of crime rate shown in diagram no. 10. 


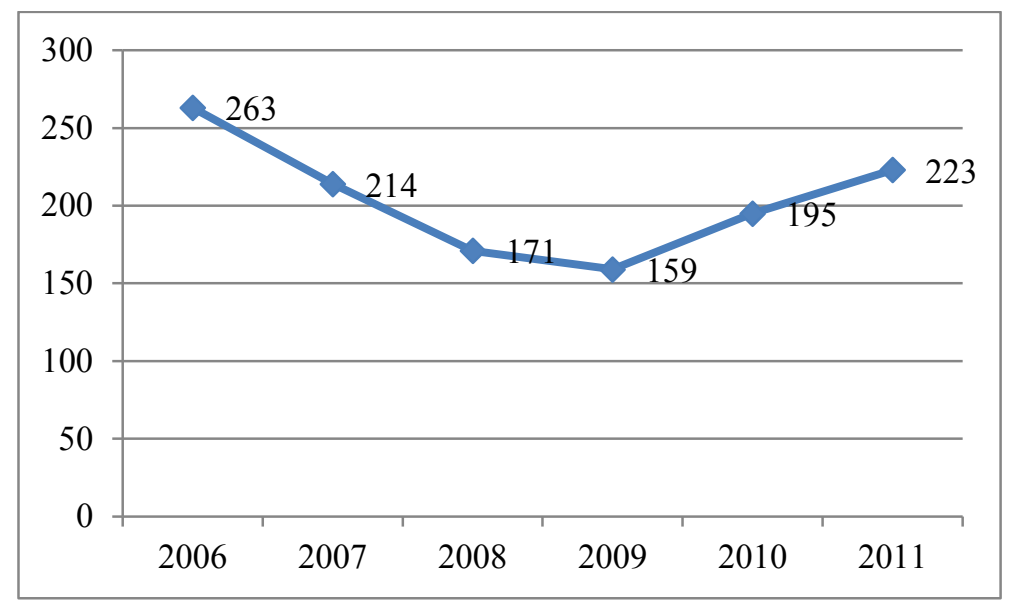

Diagram 10.: Evolution of crime rate in Romania

Source: The 2012 Statistical Yearbook of the Central Region, Regional Office of Statistics, Alba

The effects of the crisis regarding long-term growth, and thus, catching-up can be evaluated only if its relevant economic and social factors are analyzed. It is a widely accepted idea in modern growth theory that, in addition to investments, the development of human resources, including the system of education, as well as the the innovation system play a key role in longterm growth.

The way these systems are protected, respectively deteriorated during the crisis, adumbrates in what manner this development potential evolves in certain countries. As a result of the global economic crisis and the public debt growth that followed it, member states are forced to reduce financial expenses, which jeopardizes the expenditure spent on education system as well.

As long as the government does not invest more in health care and education systems, Romania will not be able to use this potential in order to help the country move forward in rankings, but the most important is to improve the quality of life for residents. The improvement of health care could increase life expectancy at birth and the time spent healthily. As a former socialist state, it is unable to compete with new challenges and has not recognized the sense of responsibility that the population and the society must be invested in because the main element of economic growth lies in human resources, especially in highly qualified ones.

Another objective is that the employed population of Romania, as human resources - one of the factors of national economy -, has to learn to react quickly and adapt to the more and more strict and demanding conditions of the labour market. Individuals have to take advantage of the opportunities offered by adult education and continue their studies.

\section{Conclusions}

It can be affirmed that both old and new member states of the European Union built their economic convergence upon involvement of foreign capital, which made them particularly vulnerable during the global financial crisis. There are differences among them regarding the depth and delay of the crisis, differences that are related to what severe imbalances encumbered the economy of certain countries before the outbreak of the crisis.

The cohesion policy must remain an important means that strengthens common European identity and represents tangible solidarity for the Romanian population already living in 
difficult times. However, it cannot be expected from the cohesion fundings to not only temper but also reverse the presented negative trends.

The evolution of the crisis until now seems to show that the strict community regulation of fiscal policies is necessary though it is not sufficient from the point of view of future integration. It is true, however, that neither the currency devaluation makes real economic adjustment avoidable, but it is probable that there will be countries that will not be able to give up the time that can be gained for adaptation in this manner.

As a result of the crisis, the convergence in integration might come to a halt not only in the short term given the fact that investments fell, the convergence between innovation systems slowed down and constraints affect education systems in cohesion countries more significantly than in non-cohesion old member states.

Romania gained great momentum in the accession up until the outbreak of the global crisis. The recession turned back the performance of national economy, while at the same time it revealed fundamental problems and imbalances. The economic recession that emerged as the result of the effects of the crisis represent a serious threat to the country's society as well.

\section{References}

1. Balázs P. 2006: Románia és Bulgária az Unióban. Az elemző (The analyst), 4, pg. 73-88., ISSN: 1784-0356

2. Banca Nationala a Romaniei (The National Bank of Romania) (2010): Annual Report, Bucharest.

3. Bunea-Bontas, C. A. - Petre, M. C. 2009: Fiscal Policy during the current Crisis. Munich Personal RePEc Archive, Paper No. 18676, accesed on 20 January 2014, http://papers.ssrn.com/sol3/papers.cfm?abstract_id=1507170, SSRN: $\underline{\text { http://ssrn.com/ab }}$ $\underline{\text { stract }=1507170}$

4. Ciulu, R. 2009: Crisis Inversion Strategies - Theory or Reality in Romania of 2009. Online source accessed on: 20 January 2014, file://C:/Users/user/Downloads/CEEOL\%20Article.PDF

5. Cotetiu, R. - Năsui V. 2010: Analysis of the evolution of Romanian economy before economic crisis. Working Paper, North University of Baia Mare.

6. European Central Bank (2010): EU Banking Structures. Frankfurt am Main

7. European Commission (2009): Five years of enlarged Europe. European Economy, No. 1.

8. Eurostat 2011: Statistics. Online source: http://epp.eurostat.ec.europa.eu/portal/page/portal/statistics/search_database

9. Human Development Reports, UNDP, 2009

10. Human Development Reports, UNDP, 2011

11. IMF, EU, EBRD... 2009: IMF, EU, EBRD: 20 milliárd eurós hitelcsomag Romániának - részletek (20 billion Euro support package to Romania - details). HVG.hu, March 25, 2009. Online source: http://hvg.hu/gazdasag/20090325 romania imf eu ebrd hitel

12. Jones, K. -Moon, G. (1987): Health, disease and society: A Critical Medical Geography. London - New York: Routledge and Kegan Paul Ltd, pg. 376., ISBN: 0-7102-1219-4

13. Marer P. 2010: A válság és Kelet-Európa. Külgazdaság, 1-2, pg. 3-31.

14. OECD 2010: OECD Economic Surveys: Romania 2010. OECD, Paris.

15. Pauwels S. - Ionita L. (2008): FDI in Romania: from low-wage competition to higher valueadded sectors. Ecfin Country Focus, vol. 5, issue 3. Online source accessed on 20 
January

2014:

http://ec.europa.eu/economy_finance/publications/publication11881_en.pdf

16. Románia Statisztikai Évkönyve 2012 (2012 Statistical Yearbook of the National Institute of Statistics, Romania), DRS Alba (Regional Office of Statistics, Alba)

17. Románia Statisztikai Hivatala (National Institute of Statistics, Romania)

18. Simon Gy. 2003: Gazdasági reformok Romániában. Külgazdaság, 7-8, pg. 57-79.

19. Talpos, I. - Avram, A. 2011: Considerations Regarding the Mix of Anticrisis Fiscal Policies in Romania. Theoretical and Applied Economics, 1, pg. 5-24, accessed on 18 January 2014, http://www.store.ectap.ro/articole/540.pdf

20. Toma, D. 2010: Austerity Measures Intensify Social Crisis in Romania. World Socialist Web Site. August 17. http://www.wsws.org/articles/2010/aug2010/roma-a17.shtml

21. Wilkinson, R. -Marmot, M.(2003): Social determinants of health: the solid facts. Copenhagen: WHO Press, 33 p., ISBN: 9289013710

22. http://logec.ro/cum-au-evoluat-veniturile-salariatilor-in-2013-comparatie-cu-europa-deest/ (date of download: January 18, 2014)

23. http://logec.ro/ce-a-adus-2013-romaniei-un-sac-plin-cu-credite-neperformante/(date of download: January 18, 2014)

24. http://logec.ro/piata-auto-are-evolutii-contradictorii-va-creste-taxa-auto/(date of download: January 18, 2014) 